\title{
How the Corruption Quadruple Helix Affects BRIC: A Case Study of Corruption in Big Emerging Economies
}

\author{
Raul Gouvea ${ }^{1}$, Manuel Montoya ${ }^{1} \&$ Steve Walsh $^{1}$ \\ ${ }^{1}$ Anderson School of Management, University of New Mexico, Albuquerque, New Mexico, USA \\ Correspondence: Manuel Montoya, MSC 05-3090, Anderson School of Management, The University of New \\ Mexico, Albuquerque, NM 87131, USA. Tel: 505-277-1182. E-mail: mrmonto@unm.edu
}

Received: March 20, 2013 Accepted: April 17, 2013 Online Published: May 30, 2013

doi:10.5539/jpl.v6n2p1

URL: http://dx.doi.org/10.5539/jpl.v6n2p1

\begin{abstract}
This study surveys the institutional conditions that produce corruption in BRIC (Brazil, Russia, India and China) nations. While this study focuses on BRIC as a case study in institutional corruption, it emphasizes the special role that each nation plays in the evolution of BRIC as a part of the global political economy. We utilize a helix structure as a means of expressing the intertwined, trans-dimensional aspects of corruption in BRIC among its various institutions. Our "quadruple helix model" reveals that the presence of a strong, meaningful alternative civil society is a significant fourth helix in several big emerging economies. This model demonstrates that data collected from multiple sources can effectively characterize the multi-dimensional systemic features of corruption if they are understood as institutional forces that evolve in sync with one another. This model demonstrates that, while the conventional wisdom that economic growth reduces corruption, bureaucratization and other institutional problems can increase corruption, especially when there are few conscious efforts to manage growth in relation to the evolution of civil society.
\end{abstract}

Keywords: global political economy, BRIC, emerging economies, institutional analysis, corruption, international business, world civil society

\section{Introduction}

Corruption practices seem ubiquitous in the global economy, with some countries business environments more affected than others. The United Nations Compact estimates that corruption adds a 10\% "corruption tax" on the cost of doing business globally and $25 \%$ additional cost of doing business with developing countries (Bajoria, 2011). Corruption affects a country's political, social, and economic development (Man, 2009). It inhibits national economic growth and development and corrodes social equality. BRIC nations, despite their rapid economic growth and development, have not been able to address the issue of corruption as effectively as one would expect, given their new importance in the global economy. These economies have not been able to match their increasing economic importance with ethical standards that imply improved levels of economic and social welfare.

Our primary purpose is to demonstrate that BRIC serves as an example of corruption that has developed partially to strong anti-national sentiment. Each nation has undergone dramatic social and political changes, and as a result, has produced a culture of resistance to national government. Thus, a long-enduring strain of civil society has developed in big emerging economies that replace the social contract that nation-states provide its people. It has been established that Brazil, Russia, India and China do operate as a significant, coordinated unit, and as a group have often been designated as the Big Emerging Markets of the global political economy (Economies) (Gou \& Guo, 2011; Cui \& Lui, 2000) or BRIC (Brazil, Russia, China, and India) countries (Walsh, 2012). Thus, the evolution of BRIC as a powerhouse in the global political economy marks the development of globally relevant patterns that have previously been under-expressed. While other forms of economic cooperation and integration have occurred through historical and cultural markers (i.e. the European Union and MERCOSUR), BRIC has occurred through channels that are not regionally cultivated. Consequently, if we are to understand the roots of corruption within nations, we must do so by first acknowledging that corruption is in part a response to perceived faults of the nation-state by its own people. What is the future of corruption in big emerging economies (as a case study for nations that have recently increased their involvement in global economic affairs) as their relationship with the world changes? 
Table 1 illustrates the ranking of BRIC in the global "Corruption Perception Index 2012" provided by Transparency International. In relation to 183 countries, BRIC nations fared considerably low if one takes into account their recent status in the global economy. For instance, Russia ranks 133 out of 183 countries evaluated.

Table 1. Corruption perception index, 2011 (Note 1)

\begin{tabular}{ccc}
\hline & Rank & Index \\
\hline Brazil & 69 & 4.3 \\
China & 80 & 3.9 \\
India & 94 & 3.6 \\
Russia & 133 & 2.8 \\
\hline
\end{tabular}

BRIC countries also indicate a propensity for public corruption, based on several other dimensions, including the World Bank's Ease of Doing Business Report, the Enterprise Survey, government expenditures as a percentage of GDP, tax burden as a percentage of GDP, the UN Human Development Index (HDI), and the lack of a free press. Figure one demonstrates that these markers can be seen as conditions that support corrupt practices, or at some level the opportunity cost involved in combating systemic corruption.

Table 2. Drivers of corruption practices in BRIC countries

\begin{tabular}{ccccc}
\hline & Brazil & India & China & Russia \\
\hline Size of Bureaucracy & $\mathrm{X}$ & $\mathrm{X}$ & $\mathrm{X}$ & $\mathrm{X}$ \\
Politicians & $\mathrm{X}$ & $\mathrm{X}$ & $\mathrm{X}$ & $\mathrm{X}$ \\
Institutions & $\mathrm{X}$ & $\mathrm{X}$ & & $\mathrm{X}$ \\
Corruption Mindset & $\mathrm{X}$ & $\mathrm{X}$ & $\mathrm{X}$ & $\mathrm{X}$ \\
Religion & & $\mathrm{X}$ & $\mathrm{X}$ & \\
Private Sector & $\mathrm{X}$ & & & $\mathrm{X}$ \\
NGOs & $\mathrm{X}$ & $\mathrm{X}$ & $\mathrm{X}$ & \\
\hline
\end{tabular}

This requires further inspection at a systemic level. Consider, for example, that ideologies are institutions that crystallize in many sub-communities with a political economy. Ideology can be mediated in many ways, including popular media, literature, music, and art. If we are to consider the complicated nature of corruption, we must fully acknowledge the many circumstances that produce corruption. Corruption must be defined in accord with the myriad of ontological and epistemological dimensions of citizenship, civil society, and public and private space. This table expresses an important point about corruption. It is not merely that the presence of any of these factors that can be indicative of corruption, but the strong presence of each of these factors in relation to one another. For example, bureaucracy alone cannot explain the presence of corruption. In fact, Max Weber suggested that bureaucracy is the fundamental way that society consolidates power, standardizes values, and creates culturally relevant norms (Mandel, 1992). But bureaucracy can deviate from the legal systems it purports to reinforce. Consequently, a bureaucracy may produce a system of administrative tasks while at the same time diminishing the legitimacy of the state. We will demonstrate that the presence of other factors, such as the presence of a long-standing history of cultural resistance to governance, the inability for these structures to produce a rationale for the work the government produces, and the extreme growth of these countries produce circumstances that defy the creation of a legitimate state. It is precisely because of the myriad nature of these relations that corruption is a nearly illegible force, a task that can better be described in terms of its complexity rather than any one dimension on its own.

\section{Corruption - A Growing Malady}

By definition, corruption is a form of unethical behavior that diminishes the institutional solvency of a nation-state and its political economy. Unlike other forms of unethical behavior, corruption (in the context 
employed herein) is an institutional phenomenon, and can be understood as a measure of a people's willingness to trust in their government and its related institutions (Donaldson \& Dunfee, 1999). One can define corruption as the abuse of a public employee's office for his/hers own benefit (Suhara, 2004). However, if one looks at the traditional definitions of corruption as stated by Plato and even Machiavelli, it relates to the nation's political process or even a nation's moral standing (Johnston, 1996). Corruption can also been perceived as a deviant behavior aiming at private gains at public sector's expense (Tummala, 2009). Corruption may have an institutional component, i.e., it happens in an institutional environment. In other words, high levels of authority independence coupled with low levels of accountability create the opportunity for corruption. In other words, when people become used to the unethical behavior produced by corruption, it becomes culturally institutionalized. The creation of a "State Capture" or a "Capture Economy" system in which outsiders are able to create a parallel system to benefit from corrupted public officers, bureaucrats, and politicians generates negative externalities to these countries societies, economies, and political systems, further fragmenting the state while compromising its cultural viability. In this "State Capture" system, outsiders are able to benefit from private arrangements at the expense of the local society and tax payers, distorting market economy signals and reallocating resources away from essential basic services. The criminal underground, in this case, would view itself as the most relevant community, because at its most sophisticated level, it replaces the state in the provision of services (i.e. providing protection to businesses and families) (Dunfee, 2006).

Corruption can also be approached a "tax" or a "corruption tax" on the economy so high levels of corruption have a double impact on the economy. The government does not collect this additional tax and most likely the funds will be moved outside the country having further negative multiplier impacts on the local economy. Thus, allocation, efficiency losses, welfare losses, and terms of trade losses, contribute to overall losses for the economy (Barry, 2009). Thus, the establishment of market rules, increasing competition, a more transparent corporate governance regime, and lower levels of economic protection will lower the ability of economic agents to expand its "capture state" strategies. The existence of institutional restraints, participation in civil society, political accountability, a competitive private sector, and a meaningfully derived sense of kinship that is culturally reinforced - all in addition to an efficiently run public sector -- lay the foundations for a less corrupted society (World Bank, 2000).

\subsection{Methodology: The Helix and Institutional Analysis}

It is obvious from this brief survey of the multi-dimensional aspects of corruption that these concerns are multi-institutional as well. Consequently, more attention must be paid to methods that engender an institutional or systemic perspective. Many have used Helical structures Leyersdorff and Etzkowitz (1996) to show the three dimensional effects of every helix or vector in their structure.

The use of helical structures in the "triple helix" has become central to these institutional methodologies. Leyersdorff and Etzkowitz (1996) presented in their seminal work on the triple helix the assertion that markets within an economy are developed in relation to a constellation of distinct interests and that mapping these concerns as they develop the general trajectory of a given economy is essential . Government policy can't merely be understood in relation to business practices. It has to be understood as one institution that emerges in tandem with other institutions that surround it - cultural, political, and socially derived institutions (Johnson, 2008). Our Quadruple helix structure emphasizes institutions, civil society, private sector and Bureaucrats and much like the Triple helix studies, our methodology is driven by institutional analysis - they are topographic views of systems that cannot be readily characterized by other empirical models. For some models, the "trees from the forest" performs the most precise means of understanding a given phenomena. However, a problem like corruption, if it is to be understood systemically, must also employ a "forest from the trees" perspective.

As a methodology, an institutional analysis can take many forms. For example, formal experimentation or historical reviews are two methods that can help one understand the circumstances that produce a given phenomenon. However, case studies are capable of being both descriptive and explanatory when complex social and political relationships are well beyond the control of researchers (Yin, 1981a, 1981b, 1983, 1989, 1993). According to Yin, case studies are a useful alternative to other empirical research models when a) the type of question requires answers at a topographic, macro scale, $b$ ) the extent of control one has over actual behavioral events is minimal; and c) the degree of focus on contemporary rather than historical events is a central feature of the research question. Questions regarding institutions largely fit within these conditions (Yin, 1989, 1993). Any attempt to answer questions about corruption as it relates to a larger system of actors fulfill these criteria, and according to Eisenhardt $(1989 ; 1991)$, they are constitutive of a unit of analysis (one case that explains a particular systemic behavior) that is obvious in theory, but difficult to penetrate beyond the institutional level. Applying Eisenhardt and Yin, this study achieves construct validity through the concept of a quadruple helix, 
which can be understood as a case study that provides multiple sources of evidence that bureaucrats, institutions (including cultural and informal value systems), government, and the private sector, all work in tandem to increase or decrease the level of corruption. When one element is ignored, all others are affected.

The strength of the quad- helix model is that it is conjectural in a holistic and systematic way. It can identify other institutional forces that may have been previously under-expressed or even ignored as part the larger system. However, a major limit to this research is its ability to reliably produce specific relational measurements. Other metrics on corruption, for example the ratio between democratic institutions and the reporting of corruption may lead one to believe that corruption has not increased in these countries, but rather that it has simply been reported more frequently. But again, these types of cases have complex models that cannot exclusively be explained by relation or rational models alone. In fact, the presence of corruption, in this specific case, implies the irrationality of the institutions involved. Hence, this paper allows a definition of corruption to produce more specific conceptual trajectories, one that researchers can apply with more relational models as these concepts are better understood.

As a method, this allows one to analyze multi-dimensional phenomena at a topographic level. This study will construct a quadruple helix by investigating and surveying the various manifestations of corruption in BRIC countries. We utilize institutions, civil society, private sector and bureaucrats as our four helical vectors. A taxonomy of corruption in these economies will validate these vectors. The multi-dimensional aspects of corruption are evident, and this review produces a taxonomy that can serve as a robust analytical approach. Figure 2 summarizes the conflation of institutional corruption as a quad-helix, one capable of addressing the myriad of corruptive practices that presently expresses itself in a piecemeal manner.

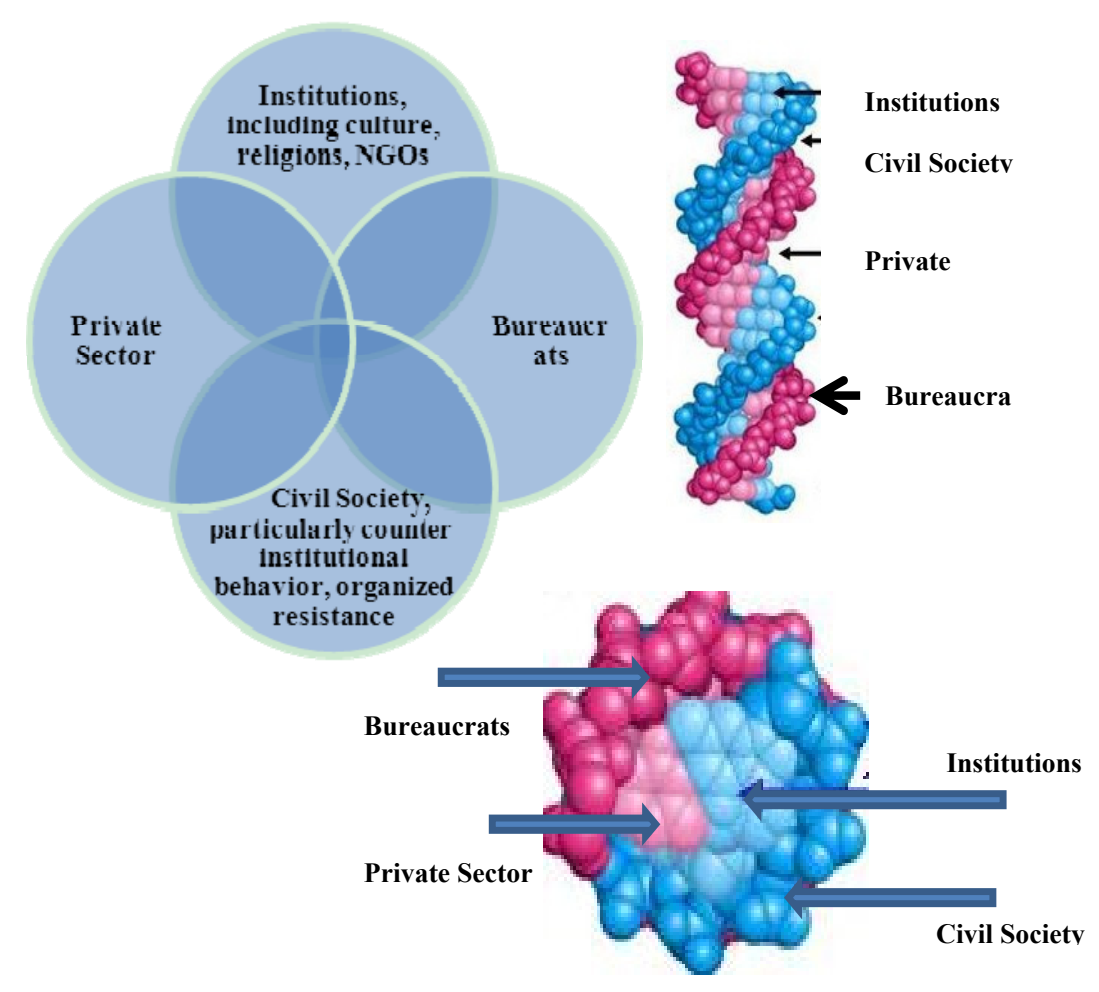

Figure 1. The corruption quadruple helix (Note 2)

\section{Taxonomy of Corruption in Big Emerging Economies}

\subsection{Russia}

Since the collapse of the Soviet Union presidents have stated their preoccupation with corruption. However, both Boris Yeltsin and Vladimir Putin were not able to restrain the increasing corruption practices in Russia. In 2008, Medvedev unveiled his "National Anti-Corruption Plan" attempting to curb corruption in Russia. As mentioned by Man (2009) it is also important to realize that in Russia levels of corruption tend to not follow a homogenous 
pattern. Apparently the Southern regions of Russia are perceived to be more corrupted than the Northern Regions of Russia. This is consistent with the notion that a cosmopolitan "North" advances while its more rural, kinship-oriented "South" remains unsophisticated and incapable of attending to producing ethical institutions (Appiah, 2006). What is more likely is that the perception of a "great civilization" remains a primary feature of Russian culture. Corruption, then, becomes an ideological institution that is constantly hidden within the idea of "greatness," which in various manifestations, erases the social realities that actual produce that corruption in the first place. Russia is one of the 116 countries that have signed the United Nation's Convention Against Corruption - UNCAC in 2003 and ratified in 2006 (Berry, 2006). Russia like other BRIC countries suffers from an endemic corruption that permeates its business environment (Weill, 2008).

Despite Yeltsin's Presidential Decree N.361 in 1992 forcing public employees to disclosure their main sources of income and the creation of the commission to combat crime and corruption, Yeltsin made the executive stronger and weakened Russia's judiciary system (Man, 2009). More recently, Vladimir Putin was not able either to curb corruption as he promised. His actions towards further strengthening the powers of the state increased levels of corruption (Orttung, 2006). Again, the greatness of the state produced the counter-cultural systems that authorized corruptive practices. Putin also sought to diminish the power and increasing role of governors, thus reinforcing a vertical chain of command, further unifying economy and judiciary system in Russia. By failing to strengthen the judiciary, Putin made "soft punishments the standard and not the exception in the Russia, increasing the perception that corruption was not being taken seriously (Martirossian, 2004). In this case, one helix cannot be isolated from the deeply embedded institutional forces located in culture and society, particularly amongst Russia's most alienated population.

During the transition years or the Perestroika phase Russia embraced western values such as the rule of law state (Suhara, 2004). Russians have traditionally distrusted their legal system; for historically, it was the primary means of controlling social values and practices. Since Russia's legal system has been rooted in its bureaucracy, Russians have approached their legal system lightly or holding a personal contempt for the law. This perception is also rooted in decades of manipulation of the legal process by the government or people in high positions. Again, the conflation of history, society, and culture makes it difficult to extract one simple approach towards characterizing corruption in Russia. Political corruption may also be classified in two types: at the top and at the bottom (Saratov, 2001). At the top we find Russia's oligarchs who benefited from Russia's economic and political transition, mainly during the earlier days of privatization.

Culturally, the Russian "blat" or an exchange of favors between groups perpetuates corruption, which produces a sense of conformity that encourages corruption from the top to bottom (Dvurechenskyhk, 2001). In Russia two expressions are used for corruption: "mzdoimstvo" and "likhoimstvo" the former is used when officials charge for delivering their duties and the latter is used when they charge for not doing their duties. Large cities, such as Moscow where the largest numbers of bureaucrats are allocated and where the greatness of Russian culture is located converge as a site of corruptive practice (Orttung, 2006). Putin's policies led to substantial increases in the number of public employees and expenditures on public employees, to a one bureaucrat per 100 Russian citizens ratio by the mid 2000s (Orttung, 2006). Salaries have been increased to public employees, including judges, but levels of corruption have not decreased. Russia, then, becomes an example of a modern democracy that is struggling to match its growth among the private sector.

\subsection{China}

Corruption has become a major issue in China's pursuit of economic development and growth in the $21^{\text {st }}$ century (Chow, 2005). China has been called a "bureaucratic market economy" that has been a major barrier for the further modernization of China's society and economy (Chow, 2002). Corruption is close to 3\% China's of GDP and is costing the country dearly producing a rapid increase in social inequalities, environmental degradation, and increasing deterioration and increasing prices of health care, education, and security services. Several factors contribute to China's corruption: a) one party political system, b) lack of accountability from independent parties, c) free media censorship, d) rapid economic reforms created a number of loopholes. Traditional cultural values extending from Confucianism valuing long term relationships and mutual favors and obligations - Guanxi perpetuates china's corrupted system. In addition, cultural beliefs also value gift giving as a part of doing business in China (DTC, 2010). Between 2003 and 2008 881,000 corrupted officials were disciplined (Chen \& $\mathrm{Zhu}, 2009$ ).The main sectors for corruption are energy, finance, transportation, telecommunications, tobacco, iron and steel, and non- ferrous metals. Regions where state controlled enterprises dominate are more prone to corruption. Most of the political leaders in these regions have family connections to China's SOEs. As a corrective measure, the government is trying to showcase class action cases to encourage support from the court of public opinion. 
However, other factors impede those efforts. China punishes only a small percentage of corrupted officials; only $6 \%$ of all perpetrators were prosecuted (Pei, 2007). In 2007, China created the "National Bureau of Corruption Prevention;" however, this initiative cannot individual investigations, and thus has no effective repercussions.

Endemic corruption could unravel China's business environment and society. For instance, The Tiananmen Square demonstrations between April 18 and June 4, 1989 was a civilian reaction against rampant corruption by officials in the 1980s (Li, 2001). This very important event in Chinese history prompted the government to start paying more attention to official's corrupt practices, primarily because social, political, and cultural responses expressed a uniform, cohesive response to corruption ( $\mathrm{Li}, 2001)$. In the past most of the corruption in China was done by mid-level bureaucrats, recently high-level cases - "da' an yao 'an" are also becoming more frequent (Chen \& Zhu, 2009). "Guandao" is another expression for corruption used to describe officials' illegal practices in manufacturing state owned plants. The diversion of products to be sold in the open market was a common practice in the industry $(\mathrm{Li}, 2001)$. The PRC Criminal Law applies to Chinese citizens, and any company organized under PRC law. In the spring of 2011, China passed amendments to its Criminal Law that clearly criminalizes bribing to non-PRC government officials and to members of international organizations (Carlson, Eliasoph \& Stratford, 2011). Since 1978, China has embraced economic reforms. Contrary to the Russian experience, China has embraced a gradual reform. For instance, the "responsibility system" led to the leasing of state-owned assets, including land. The addition of more companies in the Chinese economy and the development of a strong non-government controlled sector are all hallmarks of the Chinese economic model since 1978 (Chow, 2005). The Chinese government accounts for 35\% of China's GDP. The large influence of the Chinese state tends perpetuate corruption. Most countries with high levels of government involvement in the local economy tend to show higher levels of corruption (Emerson, 2006).

In sum, in terms of sustainability, China by allowing this corruption to become so pervasive has compromised its ability to sustain high quality economic growth and development. More importantly, it creates resentment among its population. As socio-economic disparity manifests in the myriad ways that ignoring the public usually does, the potential for disenfranchisement will produce increased corruption, especially among those who view private industry as a counter-culture to the old state-controlled market paradigm. China's National Audit Agency (NAA) indicates that between 1995 and 2006 close to US\$ 170 billion were diverted in misappropriated and misspent public funds in illegal practices (Pei, 2007). There are estimates pointing to a $10 \%$ of government spending being used as kickbacks and bribes, or $0.65 \%$ of China's GDP.

\subsection{India}

In the last few decades, India has become one of the world's most managed nations, with a very pervasive and large bureaucracy. In 1947, the government enacted the 1947 "Prevention of Corruption Act", criminalizing corruption by government officials. In 1964 the "Santhanam Committee" recommended the creation of the Central Vigilance Commission - CVC, aimed at increasing oversight of corruption practices. In 1988 the Prevention of Corruption Act further strengthened India's resolution to address public corruption. Recently, Prime Minister Manmohan Singh made several statements aiming at curbing corruption in India especially after allegations of corruption in the Common Wealth Games and in the recent mobile-licenses and housing scams (Bajoria, 2011). However, corruption is perceived to be rampant in India, encompassing the political and administrative sectors. In India one can find two main personnel-oriented sources of corruption: a) bureaucrats and b) elected politicians. The lack of accountability of public servants and the myriad of laws and statutes in India creates a fertile ground for corruption. India has 19.5 million state employees; 2 million are members of the upper echelon who control the life of 1.2 billion people, and the other 17.5 million public employees have to resort to lower levels of corruption.

India also has a traditional bureaucratic style structure, centralized government and a centralizing decision-making process, which results in low paid public employees and lack of efficient oversight of governmental activities (Chene, 2009). India's most corrupted industries are found in the education, health care, police, energy, telecommunications, transport, judiciary, taxation. The timely delivery of services is also a major source of corruption, including services as simple as the establishment of a phone connection or customs procedures. In India $91 \%$ of all bribes were demands were requested by government officials (Trace International, 2009). In 2004, 30 members of India's Parliament and close to 300 members of state Assemblies revealed criminal records (Tummala, 2009). According to the Economist Magazine, 1/5 (120 of 552 members) of the India's parliament faced criminal charges in 2008. The slow investigation process and red taped judicial system tend to favor corrupted officials. Indian society uses the expression "yatha raja, tatha praja" i.e., "the population follows the kings" (Tummala, 2009). There are claims that investigations into corrupted government officials and influential leaders in India take longer than ordinary people's criminal cases because the perception 
of status and hierarchy reinforces other forms of social inequity (Raju, 2010). Moreover, Hinduism produces a cultural prescription for forgiveness, which renders criminal activity subject to erasure at a faster rate. It thus institutionalized a high degree of leniency in India's business environment (Tummala, 2009).

\subsection{Brazil}

In the early 1990s, Brazil like the other BRICs countries went through an extensive transition phase both at the political and economic dimensions. On the political side, Brazil had its first democratic elections in the 1990s, at the same time Brazil was embarking in a massive market-oriented reforms strategy. This led to the elimination of an autarchic economic system followed by the redesigning of the role of the state in the Brazilian economy. Like in the other BRIC countries, these changes have brought additional stress in Brazil's government, institutions, bureaucracy, political system, and on Brazil's private sector now facing much higher levels of competition from global companies (Gouvea, 2004; Kume \& Piani, 2010; Luque, 2010; Silber, 2010).

In the 1990s, Brazil saw a number of state-driven cases of corruption and also a number of domestic companies driven cases of corruption. Brazil also saw the beginning of a very corrosive process were politicians and bureaucrats were also working together to expand corruption schemes (Jobim, 2004; Lucena, 2009; Magalhaes, 2010). In the early 2000s, corruption schemes gained momentum, reaching historical increases (Pereira, 2010). Corruption in Brazil took a turn to the worse in the 2000s. During the Lula administration years, institutions suffered extreme political influence; state regulating agencies were pressured to weaken standards and were headed by political appointees rather than career professionals (Nobrega, 2010). The need to establish wide political alliances led to the increased exchange of favors between the leading party and allied parties. Brazil's political system has turned into a commercial and financial bargain, a legacy of the Lula administration where political coalitions were sowed on the bases of favors (Opiniao, 2011). Another dimension of corruption was Lula's quest to increase the size of Brazil's bureaucracy aiming at increasing his political support. One dimension of this policy is Brazil's substantial number of political appointments to Brazil's already extensive bureaucracy. During the Lula years, close to 22,000 people, compared to 780 in Holland were deemed strategic appointments by the government (Alvarez, 2011; Patu, 2011; Schwartsman, 2011). In addition, this list of strategic appointments is not available to the public, increasing the likelihood of corruption and traffic of influence (Furtado, 2005).

The levels of corruption in Brazil have reached very high levels, affecting as observed earlier investments in infrastructure, health care, education, and security. For instance, since 2000 , it is estimated that close to US\$ 400 billion have been diverted from Brazil's government, in today's exchange rate. Of this amount, close to 55\% was executed at the federal level, $30 \%$ at the state level, and $19 \%$ at the municipal level. The government on average only recovers close to $1 \%$ of these stolen funds. In 2011 alone US\$ 47 billion were stolen from the government, or the equivalent of $2.3 \%$ of Brazil's GDP, enough funds to build 1.5 million popular housing, deeply alleviating Brazil's housing shortage to the poorer segments of Brazil's society (Cabral \& Diniz, 2011). In the last ten years Brazil's Accounting General Office audited 15,000 contracts between the federal government, states, municipalities and NGOs, $80 \%$ of these contracts showed irregularities (Cabral \& Diniz, 2011). Corruption has involved Brazilian institutions, bureaucrats, politicians, state run and private companies, and more recently NGOs. Most of the corruption is state driven, involving politicians from the senate and from Brazil's lower house. Aiming at their own enrichment or using public funds to use in their personal or political parties campaign. In 2011 alone, 7 ministers have been fired on charges of corruption, including President Dilma Rousseff's Chief of Staff. Contracts between NGOs and federal agencies and ministries have become a major source of corruption in Brazil. These NGOs have parental affiliation and some are used to channel funds to public officials. In 2010, 73, 089 NGOS had contracts in the value of U.S\$ 1.5billion, most of which lack government oversight (D’Araujo, 2011; Opiniao, 2011; Mello, 2011; Rangel, Pereira \& Marques, 2011; Sequeira \& Vaz, 2011).

\section{The Quadruple Corruption Model}

The Corruption Quad Model showcases the interaction of different players and factors that tend to perpetuate and expand the current wave of corruption in big emerging economy nations. The lack of accountability, lax implementation of anti-corruption laws, an expanding role of the state in the economy, a corrupted political system, where persecution of corrupted politicians is poorly executed, and a local private sector that is coerced into corruption schemes and is also an agent of corruption, have created a vicious circle of corruption and a corrupted mindset in Russia that it is hard to change. However, increasingly the costs of corruption are becoming more apparent to these countries' civil societies. Public demonstrations against corruption have spontaneously erupted in countries like Brazil in 2011. These demonstrations have become more frequent and vocal. In 
addition, in the case of Brazil the co-optation of groups that were in the past against corruption schemes, like the "National Student Association UNE" have created additional frustration in countries like Brazil. This prompts civil society to take matters in its own hands, without the traditional support of political parties or NGOs. This "BRIC Spring" movement against corruption is bound to get more vocal and stronger.

This model demonstrates that the complexity of these economies, when seen as a process that is more than the sum of its parts, helps us understand corruption in developing economies in a very practical way. More specifically, the massive growth of each nation compounded by forces that de-legitimate the government (either perceived or real) is a fully realized and complex social and political environment that defies rationalization. This is why, for example, the deregulation of the 1990s in Russia and China didn't necessary create a more efficient governmental structure. That would assume that less rules always lead to freedom and equality and more rules lead to more order. Moreover, such perceptions imply that formal government is the only force required in producing the legitimacy of the state. The quadruple helix model acknowledges that other forces legitimize political and economic behavior.

\section{Implications for Practitioners and Future Research}

Business Managers, Policy Analysts, and other practitioners within the global political economy can benefit from understanding corruption in the BRIC context for many reasons. Below are a few prominent implications:

Alternatives to national identity: All BRIC countries demonstrate the same phenomena. First, regions where state controlled enterprises dominate are more prone to corruption. Most of the political leaders in these regions have family connections, and these connections outweigh investment in national agendas or a sense of national identity or pride. As families become increasingly exposed to global events and global phenomena, the kind of social contract needed to sustain an ethical nation-state has the potential of eroding, especially when these agendas are not relevant to the way that families are encountering the world around them.

Bureaucratization is a common feature of BRIC nations. This process, compounded with the concept of "over-managing" the economic behavior of new enterprises, has caused a rift between the structures of the public and structures of government. As BRIC shifts global patterns of trade, it will consistently bring forth a tension with national bureaucracies as the focus of corruption. Managers who understand how to both navigate national requirements while building upon globally regarded processes will find themselves able to minimize their costs of doing business.

Global leadership among Big Emerging Economies is new: Most of these economies are relatively new national economies (or at least have transitioned into new, open-market economies). For this reason, it lacks the historical leadership that marks other nations as having a fully-coherent, organized civil society that can support its ideological contributions globally. This is indicative of a political-economy that has not yet fully transitioned, or is growing too fast to articulate a national identity both internally and externally - a strong marker that corruption and civil unrest prevails with a particular economy (Nawaz, 2008).

Ethical Dualism: These countries suggest a type of moral consciousness that Manabu Suhara characterizes as "ethical dualism," where people celebrated the destruction of structures of economic disparity but were nostalgic for the cultural identity made possible during that period (2004). Keeping this in mind makes one conscious of the choices made by nations is not necessarily consistent with the choices we make as emergent citizens of the global economy.

Human Resource Management: The prevailing literature on international business and human resource management asserts that employees are increasingly developing a transnational identity (Sklair, 2001). Conventional categories of staffing, such as Parent-Country National, Host-Country National, and Third-Party Country National, will become contested categories as cross-national cooperation, especially in regards to reducing national corruption, occurs. Managers will have to confront corruption as a problem related to staffing, evaluation, and hiring in places that have encountered nationally institutionalized forms of corruption.

International Trade: If corruption, in part, is due to an increased inability of national bureaucratization to serve the needs of civil society, these economies will increasingly participate in transnational corruption networks as a direct response to efforts to nationalize. Furthermore, trade regulations will become increasingly difficult to organize at the national level. If national interests are threatened, especially when corruption is present, then external trade intervention will become an increasingly important part of the trade-dispute resolution.

Global Consumption Patterns: As BRIC nations coordinate, institutional similarity among these populations will transform global consumption. Because BRIC constitutes the largest sector of economic opportunities in the world economy, economic growth will be determined by choices of business managers to cultivate relationships 
with those often seen at the base of the global income pyramid. Those who avoid this sector will not only alienate themselves from the greatest growth sector, they will also lose the advantages of newly developed social realities that bear new markets and new consumption patterns.

This also has implications for how one develops market entry strategies. If one of the major benefits of foreign direct investment for companies is based on ownership, localization, and internalization benefits, understanding the evolution of corruption as a transnational response can also help managers understand the high cost of FDI in emerging economies. Rather than focusing on FDI, it may serve managers to increasingly consider international division structures until more localized management structures are feasible.

Furthermore, any market entry that seeks to overcome the liability of foreignness must also understand the nature of corruption as a way of alienating its own nation. The terms of foreignness itself are changing fundamentally in the global economy, and as managers learn how to understand the political climate of emerging economies, we will learn that some forms of corruption can be avoided by participating in regional integration activities that may be more relevant to individuals. People across the world are increasingly becoming "flexible citizens," and it will become increasingly possible for businesses to capture the imagination of consumers without having to mediate itself through nationally-oriented ideology (Ong, 1999).

This also has implications for managers who develop Corporate Social Responsibility charters, because any attempt to localize one's efforts could potentially exacerbate corruptive practices. We have demonstrated that economic growth does not necessarily reduce corruption. In fact, certain forms of economic development may further bureaucratize corrupt institutions. Managers complicit in the development of economies that immediately exploit their own people must also consider the social and ethical implications of activity that directly validates corrupt institutions.

BRIC has inflated its number of bureaucrats in the past three decades. The increasing size of each state not only in terms of employees but also in their economic influence over those it does business with has directly influenced the tenor of each nation's business environment. The increasing number of public employees increases the chances for market distortion practices by these public employees. Increasing the accountability of political leaders and bureaucrats seems to be of paramount importance for big economic emerging nations and also future emerging nations. Increasing levels of transparency need to be introduced in addition to establishing effective sanctions on corrupted politicians and bureaucrats. The empowerment of their civil society is also of paramount importance in fighting corruption in these countries. If one cannot sustain an image of transparency, efficiency, and authority among its own population, civil society will produce a cultural response to those failings. Consequently, corruption is not merely the index of criminal and unethical behavior within a nation; it is a manifestation of the ability or inability of a nation to organize its people in times of growth and transition. The sum total of these observations confirms that a quad-helix is a useful approach in characterizing the complicated nature of corruption. It also demonstrates that one cannot merely assume that economic growth yields relative prosperity. The BRIC case demonstrates that this cannot be the case. As it emerges in conjunction with its global counterparts, the inability of nations to address regional and trans-national interactions will prove a significant indicator of competing civil authority, often emergent as corruptive or at the very least, counter-productive to the interests of each state. This is heavily underexplored in our current research on corruption. Further research needs to be developed to better understand other aspects of corruption, using a frame like the Quadruple Helix to explore the interrelated institutional forces that lead to corruption with greater nuance. From a systemic perspective, it is important for policy and economic analysts and leaders to evaluate these practices commensurate with its complex, imbedded nature. For this reason, the quad-helix serves as a meaningful contribution to the study of corruption, and by extension the study of institutions within a global political economy.

\section{References}

Alvarez, R. (2010). Os Gastos Ocultos do Planalto. O Globo, 8 de Agosto, p. 3.

Alvarez, R. (2011a). Maquina Foi Inchada ate com Servicos Terceirizados. O Globo, 16 de Janeiro, p. 3.

Alvarez, R. (2011b). Terceirizacao de Risco na Petrobras. O Globo, 20 de Fevereiro, p. 3.

Alvez, C. (2011). CGU Cria Lista de Empresas com Ficha Limpa. 14 de Fevereiro, pp. 12-13.

Appiah, K. A. (2006). Cosmopolitanism: Ethics in a World of Strangers. New York: Norton.

Bajoria, J. (2011). Corruption Threatens India's Growth. Council on Foreign Relations, March 1, Retrieved from http://www.cfr.org 
Barry, M. (2009). Corruption in Russia: A Model Exploring its Economic Costs. Caucasian Review of International Affairs, 3(4), 387-403.

Brigido, C. (2010). ONU: Brasil Tem Terceira Pior Desiqualdade do Mundo. O Globo, 23 de Julho, p. 33.

Bulgakov, M. (1996). The Master and Margarita. Translated by Diana Burgen. New York: Vintage.

Cabral, O., \& Diniz, L. (2011). A Vinganca Contra os Corruptos. Veja, Edicao 2240, Ano 44, No.43, pp. 76-82.

Carlson, E., Eliasoph, E., \& Stratford, T. (2011). China Amends Criminal Law to Cover Foreign Bribery. Retrieved from http://www.cov.com

Chen, G., \& Zhu, J. J. (2009). China's Recent Clamdown on High-Stakes Corruption. EAI Background Brief No. 490.

Chene, M. (2009). Overview of Corruption and Anti-Corruption Efforts in India. U4 Anti-Corruption Resource Centre.

Chow, G. (2002). China's Economic Transformation. Oxford: Blackwell.

Chow, G. (2005). Corruption and China's Economic Reform in the Early $21^{\text {st }}$ Century. CEPS Working Paper No.116. Princeton: Princeton University.

Colon, L. (2011). Empresa de Senador Leva R $\$ 57$ milhoes da Petrobras em Contratos sem Licitacao. O Estado de Sao Paulo, 3 de Julho, p.A.4.

Cui, G., \& Liu, Q. (2000). Regional market segments of China: opportunities and barriers in a big emerging market. Journal of Consumer Marketing, 17(1), 55-72. http://dx.doi.org/10.1108/07363760010309546

D’Araujo, M. (2011). Ares de Transicao. O Estado de Sao Paulo, 5 de Junho, p.J.4.

Donaldson, T., \& Dunfee, T. W. (1999). Towards a Unified Conception of Business Ethics: Integrative Social Contracts Theory. Academy of Management Review, 19(2), 252-284.

Dunfee, T. (1991). Business Ethics and Extant Social Contracts. Business Ethics Quarterly, 1(1), 23-51.

Dunfee, T. (2006). A Critical Perspective of Integrative Social Contracts Theory: Recurring Criticisms and Next Generation Research Topics. Journal of Business Ethics, 68(3), 303-328. http://dx.doi.org/10.1007/s10551-006-9016-6

Earle, J. S., Spicer, A., \& Peter, K. S. (2010). The Normalization of Deviant Organizational Practices: The Growth of Wage Arrears in Russia, 1992-1998. Academy of Management Journal (Online Edition).

Egger, P., \& Hannes, W. (2005). Evidence on corruption as an incentive for foreign direct investment. European Journal of Political Economy, 21(4), 932-952. http://dx.doi.org/10.1016/j.ejpoleco.2005.01.002

Eisenhardt, K. M. (1989). Building theories from case study research. The Academy of Management Review, 14(4), 532-550.

Eisenhardt, K. M. (1991). Eisenhardt, Better stories and better constructs: the case for rigor and comparative logic. The Academy of Management Review, 16(4), 620-627.

Emerson, P. M. (2006). Corruption, competition, and democracy. Journal of Development Economics, 81(1), 193-212. http://dx.doi.org/10.1016/j.jdeveco.2005.04.005

Escosteguy, D. (2010). Fui Extorquido na Casa Civil. Veja, 20 de Outubro, Edicao 2187, Ano 43, No.42, pp. 82-84.

Ferreira, F., Wiziack, J., \& Sciarretta, T. (2011). PF Apura Doacoes do PanAmericano ao PT. Folha de Sao Paulo, 28 de Outubro, p.B.5.

Fortes, L., \& Lirio, S. (2010). Os Filhos de Erenice. Carta Capital, 22 de Setembro, Ano XVI, No.614, pp. 34-37.

Furtado, C. (2005). Corrupcao, Praga Mundial. Desafios do Desenvolvimento, Ano 2, No.12, pp. 46-53.

Guo, B., \& Guo, J. (2011). Patterns of technological learning within the knowledge systems of industrial clusters in emerging economies: Evidence from China. Technovation, 31(2-3), 87-104. http://dx.doi.org/10.1016/j.technovation.2010.10.006

IBGE. (2010). Fundacoes e Associacoes Privadas sem Fins Lucartivos no Brasil. Rio de Janeiro: IBGE.

Jakobson, L. (2001). Public Management in Russia: Changes and Inertia. International Public Management Journal, 4, 27-48. http://dx.doi.org/10.1016/S1096-7494(01)00040-X 
Jobin, N. (2004). Por um Judiciario Comprometido com o Desenvolvimento do Pais. In Joao Paulo dos Reis Velloso (Ed.), Economia do Conhecimento, Crescimento e Inclusao Social (pp. 745-754). Rio de Janeiro: Jose Olympio Editora.

Johnston, M. (1996). The Search for Definitions: the Vitality and Politics and the Issue of Corruption. International Social Science Journal, 149, 321-335.

Koslinski, M., \& Reis, E. (2008). Transnational and Domestic Relations of NGOs in Brazil. World Development, 37(3), 714-725. http://dx.doi.org/10.1016/j.worlddev.2008.06.005

Kume, H., \& Piani, G. (2010). Comercio Exterior e Politica Comercial no Brasil. In A. D. Netto (Ed.), O Brasil do Seculo XXI (pp. 79-92). Sao Paulo: Editora Saraiva.

Li, W. (2001). Corruption during the Economic Transition in China. Mimeo, Darden School of Business, University of Virginia.

Lucena, E. (2009). Imprensa, Midia, e Sociedade em Transformacao. In Joao Paulo dos Reis Velloso (Ed.), Na Crise Global, As Oportunidades do Brasil e a Cultura da Esperanca (pp. 261-266). Rio de Janeiro: Jose Olympio Editora.

Luque, C. (2010). Crescimento da Economia Brasileira: Desafios e Perspectivas. In A. D. Netto (Ed.), O Brasil do Seculo XXI (pp. 431-448).

Magalhaes, J. (2010). Estrategias e Modelos de Desenvolvimento. In P. Passarinho (Ed.), Os Anos Lula (pp. 19-34). Ro de Janeiro: Editora Garamond.

Magalhaes, L. (2009). A Evolucao da Carga Tributaria. O Globo, 24 de Junho, p. 19.

Man, M. (2009). Political Corruption in Russia: An Evaluation of Russia's Anti-Corruption Strategies, 1991-2009. Polis Journal, 2(Winter), 1-40.

Mandel, E. (1992). Power and Money: A Marxist Theory of Bureacracy. London: Verso.

Mauro, P. (1995). Corruption and Growth. The Quarterly Journal of Economics, 110(3), 681-712. http://dx.doi.org/10.2307/2946696

Mello, F. (2011). O Raio X da Corrupcao. Veja, 8 de Junho, Edicao 2220, Ano 44, No.23, pp. 121-125.

Mironov, B. (1990). The Russian Peasant Commune After the Reforms of the 1860s. In B. Eklof, \& S. Frank (Eds.), The World of the Russian Peasant: Post-Emancipation Culture and Society. Boston: Unwin Hyman.

Nawaz, F. (2008). Corruption in Fast-Growing Markets: Lessons from Russia and Vietnam. U4 Expert Answer. Anti-Corruption Resource Centre.

Nobre, M. (2011). A Politica da Queda de Braco. O Estado de Sao Paulo, 24 de Julho, p.J.3.

Nobrega, M. (2010). O Custo Oculto do Governo Lula. Veja, 11 de Agosto, edicao 2177, No.32, Ano 43, p.120.

Number of Net. (2010). Number of NGOS in India. Retrieved from http://www.numberofnet.net

Ong, A. (1999). Flexible Citizenship: The Cultural Logics of Transnationality. Durham, N.C.: Duke University Press.

Orttung, R. (2006). Causes and Consequences of Corruption in Putin's Russia. PONARS Policy Memo, No.430. Retrieved from http://csis.org/files/media/csis/pubs/pm_0430.pdf

Patu, G. (2011a). Petistas Controlam 60\% dos Cargos do Governo Federal. Folha de Sao Paulo, 16 de Janeiro, p.A.4.

Patu, G., \& Odilla, F. (2011). Gastos Publicos com Consultorias Chegam a R\$ 2 billhoes ao Ano. Folha de Sao Paulo, 5 de JUnho, p.A.10.

Pei, M. X. (2007). Corruption Threatens China's Future. Policy Brief, 55. Washington, D.C: Carnegie Endowment for International Peace.

Pereira, M. (2010). O Lulismo no Poder. Rio de Janeiro: Editora Record.

Phyllis, D., \& Orttung, R. (2005). Explaining Patterns of Corruption in the Russian Regions. World Politics, 57(4), 500-529. http://dx.doi.org/10.1353/wp.2006.0008

Raju, R. (2010). Fighting Corruption. How Serious is India? IPCS Issue Brief No.158. New Delhi: Institute of Peace and Conflict Studies.

Ramos, M., \& Loyola, L. (2011). Nem A Melhor delas Escapa. Epoca, 24 de Outubro, No.701, pp. 56-57. 
Rangel, R., Pereira, P., \& Marques, H. (2011). Pobres Homens Ricos. Veja, 27 de Julho, Edicao 2227, Ano 44, No.30, pp. 61-66.

Rolli, C., \& Fernandes, F. (2005). Com 1/3 da Renda do Pais, Setor Imformal Resiste a Retomada. Folha de Sao Paulo, 9 de Janeiro, p.B.4.

Schwartsman, H. (2011). A Porteira da Corrupcao. Folha de Sao Paulo, 28 de Outubro, p.A.2.

Sequeira, C., \& Vaz, L. (2011). Ministro Passos Tortos. Isto E, 20/7, Ano 35, No.2175, p.38-41.

Shelley, L. (2005). International Dimensions of Corruption: The Russian Case.

Shlapentokh, V. (1996). Russia's Acquiescence to Corruption Makes the State Machine Inept. Communist and post-Communist Studies, 36(2), 151-161. http://dx.doi.org/10.1016/S0967-067X(03)00023-0

Silber, S. (2010). O Brasil do Contexto do Comercio Mundia. In D. Neto (Ed.), O Brasil do Seculo XXI (pp. 49-78). Sao Paulo: Editora Saraiva.

Sklair, L. (2001). The Transnational Capitalist Class. Oxford: Blackwell.

Stefano, F., \& Paduan, R. (2011). Choque de Brasil. Exame, Edicao 1000, Ano 45, No.17, p.112-118.

Sterling, C. (1994). Containing the New Criminal Nomenklatura. In L. Raine, \& F. Ciluffo (Eds.), Global Organized Crime: The New Empire of Evils (pp. 106-111). Washington, D.C: Center for Strategic and International Studies.

Suhara, M. (2004). Corruption in Russia: A Historical Perspective. In Slavic Research Center, Hokkaido University Annual Report (pp. 383-403).

The Economist. (2011, November 19). Russia's Place, Putin his Place, 401(8760), 55-56.

Trade Council Denmark-China. (2011). Corruption in China. Retrieved from http://www.dtchina.um.dk

Tummala, K. (2009). Combating Corruption: Lessons out of India. International Public Management Review, 10(1), 34-58.

Valor, O. (2011). Reforma Pode Ajudar a Descriminalizar a Politica. Valor, 27 de Julho, p.A.12.

Waduge, S. (2008). Questioning NGO Corruption \& Neutrality. World Institute for Asian Studies, 12(364). Retrieved from http://www.asiantribune.com/?q=node/13213

Walsh, P. (2012), Innovation Nirvana or Innovation Wasteland? Identifying commercialization strategies for small and medium renewable energy enterprises. Technovation, 32(1), 32-42. http://dx.doi.org/10.1016/j.technovation.2011.09.002

Weill, L. (2008). How Corruption Affects Bank Lending in Russia. BOFIT Discussion Papers, (18). Helsinki: Bank of Finland.

World Bank. (2000). Multi-Pronged Anticorruption Strategy. Washington, D.C: World Bank.

Yin, R. K. (1981a). The Case Study as a Serious Research Strategy, Knowledge: Creation, Diffusion, Utilization (p. 3, 97, \& 114).

Yin, R. K. (1981b). The Case Study Crisis: Some Answers. Administrative Science Quarterly, 26, 58-65. http://dx.doi.org/10.2307/2392599

Yin, R. K. (1983). The Case Study Method: An Annotated Bibliography. COSMOS Corporation, Washington, D.C.

Yin, R. K. (1989). Case Study Research: Design and Methods. Sage, Newbury Park, CA.

Yin, R. K. (1993). Application of case-study research. Sage, Newbury Park, CA.

\section{Notes}

Note 1. Source: Transparency International, 2012. Index runs between a scale of 1 to 10,1 being very corrupt. The sample covers 183 countries.

Note 2. Original Helix art appears in http: //www.biochem.arizona.edu/classes/bioc461/Chapter5Part1Notes.htm

\section{Copyrights}

Copyright for this article is retained by the author(s), with first publication rights granted to the journal.

This is an open-access article distributed under the terms and conditions of the Creative Commons Attribution license (http://creativecommons.org/licenses/by/3.0/). 